\title{
Effect of Planting Methods, Maize Hybrids and Nitrogen Levels on Nutrient Uptake of High Quality Protein Maize (Zea mays L.)
}

\author{
Dheeraj Kr. Tiwari", V.S. Hooda, S.K. Thakral, Ashok Yadav and M.K. Sharma \\ Department of Agronomy, CCS Haryana Agricultural University, Hisar-125004 \\ (Haryana), India \\ *Corresponding author
}

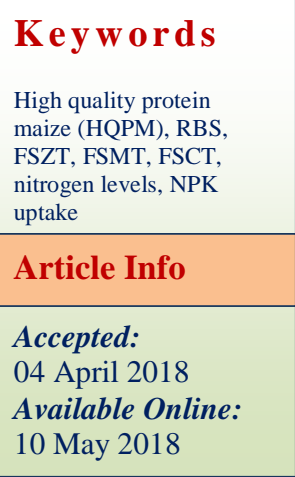

\section{A B S T R A C T}

A field experiment entitled, "Performance of maize (Zea mays L.) hybrids under different planting methods and nitrogen levels" was conducted at Agronomy research farm, CCS Haryana Agricultural University, Hisar during kharif 2013 and 2014. The experiment consisted of four planting techniques viz. Raised Bed System (RBS), Flat Sowing with Zero Tillage (FSZT), Flat Sowing with Minimum Tillage (FSMT) and Flat Sowing with Conventional Tillage (FSCT) in main plots and two maize hybrids viz. HQPM-1 and HQPM-5 and three nitrogen levels viz. 120,150 and $180 \mathrm{~kg} \mathrm{~N}^{-1}$ in sub plots with combination, were tested in split plot design with three replications. Results obtained from this experiment indicated that the highest nutrient uptake by maize was recorded with FSZT as compared to RBS, FSMT and FSMT. The highest nitrogen uptake by maize (91.50 kg ha ${ }^{-1}$ by grain and 59.01 by stover during 2013 and $86.28 \mathrm{~kg} \mathrm{ha}^{-1}$ by grain and $53.28 \mathrm{~kg} \mathrm{ha}^{-1}$ by stover during 2014 crop seasons, respectively) was recorded with FSZT planted maize. Likewise, between the maize hybrids HQPM-5 recorded significantly higher nitrogen uptake over HQPM-1 hybrid during both the crop seasons. Among the nitrogen levels $\mathrm{N}$ uptake was found to enhance with successive levels of nitrogen from 120 $\mathrm{kg} \mathrm{N} \mathrm{ha}{ }^{-1}$ to $180 \mathrm{~kg} \mathrm{~N}^{-1}$ during 2013 and 2014 crop seasons. Effects of different treatments on uptake of phosphorus and potassium by maize grain and stover were almost similar to nitrogen uptake. Application of nitrogen increased significantly NPK uptake.

\section{Introduction}

Maize (Zea mays L.) is a one of the important staple food crops of the world and ranks next only to wheat and rice as the third most important crop in the world. Maize is the most important crop in world's economy, grown over an area of $177 \mathrm{~m}$ ha with a total production of $967 \mathrm{mt}$. India ranks fourth in area and sixth in production of maize. In India, it is an important cereal crop next only to rice and wheat with acreage of around 9.4 million hectares and production of 23.0 million tonnes with the highest per day productivity (Anonymous, 2015a). Maize was grown in an area of 9,000 hectare with production of 27,000 tonnes and productivity of $3,000 \mathrm{~kg}$ per hectare in Haryana during 2014-2015 (Anonymous, 2015b). Haryana state has an ample scope to further increase acreage and productivity of maize as it can be strong candidate in the derive of crop diversification 
to displace puddled transplanted rice. In the recent years, maize has replaced many traditional crops and its area is increasing very fast in Haryana due to severe incidence of pests and diseases and greater rainfall abnormality, the traditional crops became non profitable. In addition to many above good characters of maize, easiness in cultivation, free from pest and diseases, high yield, better market price, better soils and good rainfall with well distribution has become popular and more profitable. In these areas maize attained a commercial crop status. Still there is lot of scope to increase the present maize yields. Maize crop management involves decision making on several cultural/agronomic practices aimed to maximize grain yields like planting methods (CA based RCTs), improved varieties and proper nutrient management. Interventions in the form of new resource conservation technologies (RCTs) like zerotillage and furrow irrigated raised bed system (FIRBS) coupled with crop diversification by including maize in place of rice may be a viable solution. The mean grain yield of hybrid genotypes grown on FIRBS yielded $44 \%$ more than conventional practice and $12 \%$ with no-till practices (Jat et al., 2007). The total water use in maize under FIRBS (2030.3 $\left.\mathrm{m}^{3} \mathrm{ha}^{-1}\right)$ and no-tillage $\left(2722.8 \mathrm{~m}^{3} \mathrm{ha}^{-1}\right)$ were remarkably reduced by 84.3 and $62.8 \%$, respectively compared to conventional tillage $\left(3231.0 \mathrm{~m}^{3} \mathrm{ha}^{-1}\right)$ practice. Further, the water productivity ( $\mathrm{kg}$ grain $\mathrm{m}^{3}$ water) was also considerably higher under FIRBS (3.05) and no-tillage (2.02) compared to conventional practice (1.33). Replacement of common maize by hybrid quality protein maize (HQPM) is the most effective and attractive measure to meet quality protein needs and to raise the nutritional status of human beings and animals. HQPM production in zero-tillage would help India become both "Food secure" and "Nutritional secure" (Jat et al., 2007) and is also "environmental secure". Selection of hybrid varieties of maize and different planting methods at suitable dose of nutrients particularly $\mathrm{N}$ is a serious problem in north India for quantitative and qualitative production of maize. Utilization and improvement of soil resources is of paramount importance for enhancing crop production. Adequate information is not available on the performance of maize hybrids under different planting methods and varying dose of nutrients particularly N. Proposed investigation is basically aimed to explore possibilities of crop diversification by including maize in the system as an alternate of rice and also to find out optimum dose of $\mathrm{N}$ besides suitable planting method. Saving in irrigation water, improvement in soil health and environmental protection will be possible broader outcome besides attaining higher productivity and profitability.

\section{Materials and Methods}

A field experiment was conducted site during the kharif seasons of 2013 and 2014 at the Agronomy Research Farm, of CCS Haryana Agricultural University, (situated at $29^{\circ} 10^{\prime}$ North latitude and $75^{\circ} 46^{\prime}$ East longitudes at an elevation of $215.2 \mathrm{~m}$ above mean sea level) Hisar, India. The soil of the field is derived from Indo-Gangetic alluvium soil is sandy loam in texture. Four representative soil samples were drawn from different places in the experimental field from $0-15 \mathrm{~cm}$ depth before starts of the experiments. Composite samples, prepared by passing through $2 \mathrm{~mm}$ mesh sieve, were analysed. The details of physical and chemical properties of the experimental field along with the method followed are given in table 1 and 2. The rainfall received during the kharif crop seasons of 2013 and 2014 was 661.7 and $212.1 \mathrm{~mm}$, respectively. The mean weekly maximum temperature in kharif 2013 ranged between 31.3 to $39.6^{\circ} \mathrm{C}$ and minimum between 22.4 to $28.4^{\circ} \mathrm{C}$, while, their corresponding values in kharif 2014 were 32.5 
to $42.3^{\circ} \mathrm{C}$ and 21.5 to $28.6^{\circ} \mathrm{C}$. The mean weekly morning and evening relative humidity ranged between 67 to 96 per cent and 33 to 81 per cent in kharif 2013 and between 60 to 94 per cent and 32 to 72 per cent in the year kharif 2014, respectively. The experiment consisted of four planting techniques viz. Raised bed system (RBS), Flat sowing with Zero tillage (FSZT), Flat sowing with Minimum tillage (FSMT) and Flat sowing with Conventional tillage (FSCT) in main plots and two maize hybrids viz. HQPM-1 and HQPM-5 and three nitrogen levels viz. 120, 150 and $180 \mathrm{~kg} \mathrm{~N} \mathrm{ha}^{-1}$ in sub plots with combination. The 24 treatment combinations were tested in split plot design with three replications, presented in table 3 .

Nitrogen, phosphorus and potassium were applied trough urea, DAP and MOP as per the treatments. All the field operations such as hoeing, irrigation etc. Were done as and when required. The harvested grain and stover from each plot was weighted in situ on salter balance in $\mathrm{kg} \mathrm{plot}^{-1}$. A random sample of 500 $\mathrm{g}$ was taken from each plot at the time of harvesting of grains as well as stover. The samples were first dried in the electric hot air oven at the temperature of $70 \pm 5^{\circ} \mathrm{C}$ till constant weight. The samples of grain and stover were analyzed by following standard procedures in the laboratory. Total $\mathrm{N}$ in grain and stover were analyzed by colorimetric (Nessler's reagent) method (Linder, 1944) and total $\mathrm{P}$ analyzed by Vanadomolybdo phosphoric yellow colour method (Koenig and Johnson, 1942). The total $\mathrm{K}$ in grain and stover were analyzed by flame photometer. Data collected during the study were statistically analyzed by using the technique of analysis of variance (ANOVA) described by (Panse and Sukhatme 1978). To judge the significant difference between means of two treatments, the critical difference (C.D.) was worked out using following formula, cited in Cochran and Cox (1959).

\section{Results and Discussion}

\section{Nutrients uptake by high quality protein maize}

The data pertaining to nitrogen uptake ( $\mathrm{kg}$ $\mathrm{ha}^{-1}$ ) by grain is given in Table 4. Among different planting techniques maximum nitrogen uptake by grain was recorded by zero tilled maize (FSZT), which was significantly better than FSMT and FSCT but was at par to raised bed system (RBS).

Between the maize hybrids, HQPM-5 hybrid was found to superior over HQPM-1 hybrid for the uptake of nitrogen during both the crop seasons. Nitrogen uptake by grain was found to increased with increasing fertility levels. Among different $\mathrm{N}$ levels maximum nitrogen uptake by grain was recorded with $180 \mathrm{~kg}$ $\mathrm{Nha}^{-1}$ and lowest with $120 \mathrm{~kg} \mathrm{Nha}^{-1}$ during both the crop seasons.

The data on interaction effect of various planting methods with nitrogen levels on nitrogen uptake by grain (Table 5) revealed that FSZT planted maize with nitrogen at the rate of $180 \mathrm{~kg} \mathrm{ha}^{-1}$ (N3) had significantly highest $\mathrm{N}$ uptake by maize grain $(101.45 \mathrm{~kg}$ $\mathrm{ha}^{-1}$ and $95.52 \mathrm{~kg} \mathrm{ha}^{-1}$ in the respective two seasons) over the FSCT with N3, N2 and N1 combinations, but all other treatment combinations at par with FSZT planted maize with nitrogen at the rate of $180 \mathrm{~kg} \mathrm{ha}^{-1}(\mathrm{~N} 3)$.

The data pertaining to nitrogen uptake ( $\mathrm{kg}$ ha ${ }^{1}$ ) by stover is given in table 4 . The nitrogen uptake by maize stover was significantly higher under FSZT as compared to FSMT and FSCT. However, FSZT was at par to raised bed system (RBS) in respect of nitrogen uptake by maize stover. Nitrogen uptake by grain was found to increase with increasing fertility levels. Nitrogen uptake by stover was found to increase with HQPM-5 maize hybrid over the HQPM-1 hybrid. 
Table.1 Physico-hydrological properties of experimental soil

\begin{tabular}{l} 
Component \\
\hline Sand \\
\hline Silt \\
\hline Clay \\
\hline Textural class \\
\hline Bulk density, g $\mathrm{cm}^{-3}$ \\
\hline Infiltration rate, $\mathrm{mm} \mathrm{hr}^{-1}$ \\
\hline FC at $-0.03 \mathrm{MPa}$ \\
\hline PWP at $-1.5 \mathrm{MPa}$ \\
\hline A vailable water, \% \\
\hline
\end{tabular}

\begin{tabular}{|c|c|}
\hline Fraction, \% & Method of Estimation \\
\hline 57.3 & \multirow{2}{*}{$\begin{array}{l}\text { International pipette method } \\
\text { (Piper 1966) }\end{array}$} \\
\hline 24.5 & \\
\hline 18.2 & \\
\hline \multicolumn{2}{|l|}{ Sandy loam } \\
\hline 1.39 & Core sampling (Piper 1966) \\
\hline 4.27 & $\begin{array}{l}\text { Ring infiltrometers } \\
\text { (Reddy 2012) }\end{array}$ \\
\hline 19.89 & \multirow{2}{*}{$\begin{array}{l}\text { Pressure membrane apparatus } \\
\text { (Richards 1954) }\end{array}$} \\
\hline 5.93 & \\
\hline 13.85 & \\
\hline
\end{tabular}

Table.2 Initial chemical properties of experimental soil

\begin{tabular}{|c|c|c|c|}
\hline Soil parameter & Value & Status & Method of estimation \\
\hline $\begin{array}{l}\text { Soil } \mathrm{pH}(1: 2 \text { soil water } \\
\text { suspension) }\end{array}$ & 8.04 & Alkaline & $\begin{array}{l}\text { Glass electrode } \mathrm{pH} \text { meter method (Jackson } \\
\text { 1973) }\end{array}$ \\
\hline $\begin{array}{l}\mathrm{EC}\left(\mathrm{dSm}^{-1} \text { at } 25^{\circ} \mathrm{C}\right)(1: 2 \\
\text { soil water suspension })\end{array}$ & 0.20 & - & $\begin{array}{l}\text { Conductivity bridge method (Richards } \\
\text { 1954) }\end{array}$ \\
\hline Organic carbon $(\%)$ & 0.45 & Medium & $\begin{array}{l}\text { Walkley and Black's wet Oxidation method } \\
\text { (1934) }\end{array}$ \\
\hline Available $\mathrm{N}\left(\mathrm{kg} \mathrm{ha}^{-1}\right)$ & 142.0 & Low & $\begin{array}{l}\text { Alkaline permanganate method (Subbiah } \\
\text { and Asija, 1956) }\end{array}$ \\
\hline Available $\mathrm{P}_{2} \mathrm{O}_{5}\left(\mathrm{~kg} \mathrm{ha}^{-1}\right)$ & 22.7 & High & Olsen’smethod (Olsen et al., 1954) \\
\hline Available $\mathrm{K}_{2} \mathrm{O}\left(\mathrm{kg} \mathrm{ha}^{-1}\right)$ & 276.0 & Medium & Flame photometer method (Richards 1954) \\
\hline
\end{tabular}

Table.3 Details of treatments used in experiments

\begin{tabular}{|l|l|c|}
\hline A. & Planting methods & Symbol used \\
\hline i. & Raised bed system (RBS) & P1 \\
\hline ii. & Flat sowing with zero tillage (FSZT) & P2 \\
\hline iii. & Flat sowing with minimum tillage (FSMT) & P3 \\
\hline iv. & Flat sowing with conventional tillage (FSMT) & P4 \\
\hline B. & Maize hybrids & Symbol used \\
\hline i. & HQPM-1 & V1 \\
\hline ii. & HQPM-5 & V2 \\
\hline C. & Nitrogen levels $\left(\mathbf{k g ~ h a}^{-\mathbf{1}}\right)$ & Symbol used \\
\hline i. & 120 & N1 \\
\hline ii. & 150 & N2 \\
\hline iii. & 180 & \\
\hline
\end{tabular}


Table.4 Nitrogen, phosphorus and potassium uptake by maize crop as influenced by various planting methods, maize hybrids and nitrogen levels

\begin{tabular}{|c|c|c|c|c|c|c|c|c|c|c|c|c|}
\hline \multirow[t]{3}{*}{ Treatments } & \multicolumn{4}{|c|}{ Nitrogen uptake (kg ha $\left.{ }^{-1}\right)$} & \multicolumn{4}{|c|}{ Phosphorus uptake $\left(\mathrm{kg} \mathrm{ha}^{-1}\right)$} & \multicolumn{4}{|c|}{ Potassium uptake $\left(\mathrm{kg} \mathrm{ha}^{-1}\right)$} \\
\hline & \multicolumn{2}{|c|}{2013} & \multicolumn{2}{|c|}{2014} & \multicolumn{2}{|c|}{2013} & \multicolumn{2}{|c|}{2014} & \multicolumn{2}{|c|}{2013} & \multicolumn{2}{|c|}{2014} \\
\hline & Grain & Stover & Grain & Stover & Grain & Stover & Grain & Stover & Grain & Stover & Grain & Stover \\
\hline \multicolumn{13}{|c|}{ Planting methods } \\
\hline $\begin{array}{l}\text { Raised bed } \\
\text { system }\end{array}$ & 81.91 & 51.20 & 77.09 & 46.50 & 20.12 & 11.60 & 19.15 & 11.97 & 18.02 & 105.98 & 18.17 & 95.05 \\
\hline FSZT & 91.50 & 59.01 & 86.28 & 53.28 & 22.24 & 13.20 & 21.04 & 13.26 & 20.03 & 114.44 & 20.03 & 102.87 \\
\hline FSMT & 80.83 & 49.48 & 76.11 & 44.65 & 19.19 & 10.32 & 18.28 & 11.19 & 17.12 & 106.04 & 17.36 & 94.47 \\
\hline FSCT & 71.06 & 41.17 & 67.11 & 37.94 & 17.51 & 9.29 & 16.41 & 10.08 & 15.59 & 99.60 & 15.54 & 88.51 \\
\hline SEm \pm & 0.50 & 0.07 & 0.53 & 0.29 & 0.12 & 0.05 & 0.16 & 0.12 & 0.09 & 0.23 & 0.09 & 0.43 \\
\hline CD at $(5 \%)$ & 1.75 & 0.24 & 1.85 & 1.00 & 0.43 & 0.17 & 0.57 & 0.43 & 0.33 & 0.80 & 0.32 & 0.149 \\
\hline \multicolumn{13}{|c|}{ Maize hybrids } \\
\hline HQPM-1 & 78.04 & 48.46 & 73.88 & 44.12 & 18.86 & 10.56 & 17.93 & 11.21 & 16.89 & 104.17 & 17.04 & 92.99 \\
\hline HQPM-5 & 84.62 & 51.97 & 79.41 & 47.07 & 20.66 & 11.64 & 19.51 & 12.04 & 18.49 & 108.86 & 18.50 & 97.46 \\
\hline SEm \pm & 0.36 & 0.08 & 0.41 & 0.13 & 0.09 & 0.03 & 0.11 & 0.08 & 0.9 & 0.19 & 0.12 & 0.28 \\
\hline CD at $(5 \%)$ & 1.03 & 0.25 & 1.18 & 0.39 & 0.26 & 0.08 & 0.33 & 0.25 & 0.27 & 0.55 & 0.36 & 0.79 \\
\hline \multicolumn{13}{|c|}{ Nitrogen levels $\left(\mathrm{kg} \mathrm{ha}^{-1}\right)$} \\
\hline 120 & 72.18 & 44.86 & 68.16 & 41.07 & 16.91 & 9.03 & 16.20 & 10.20 & 15.03 & 99.11 & 15.36 & 88.51 \\
\hline 150 & 81.87 & 49.98 & 77.05 & 45.39 & 19.95 & 11.13 & 18.91 & 11.63 & 17.83 & 106.47 & 17.92 & 95.16 \\
\hline 180 & 89.93 & 55.80 & 84.73 & 50.32 & 22.43 & 13.15 & 21.05 & 13.05 & 20.21 & 113.96 & 20.04 & 102.00 \\
\hline SEm \pm & 0.44 & 0.10 & 0.50 & 0.16 & 0.11 & 0.03 & 0.14 & 0.10 & 0.11 & 0.23 & 0.14 & 0.34 \\
\hline CD at $(5 \%)$ & 1.26 & 0.29 & 1.45 & 0.48 & 0.32 & 0.10 & 0.41 & 0.31 & 0.33 & 0.68 & 0.41 & 0.79 \\
\hline
\end{tabular}


Table.5 Interaction effect of planting methods and nitrogen levels on nitrogen, phosphorus and potassium uptake by maize crop

\begin{tabular}{|c|c|c|c|c|c|c|}
\hline \multirow[t]{3}{*}{ Treatments } & \multicolumn{3}{|c|}{2013} & \multicolumn{3}{|c|}{2014} \\
\hline & N1 & $\mathbf{N} 2$ & N3 & N1 & N2 & N3 \\
\hline & \multicolumn{6}{|c|}{ Nitrogen uptake by grain $\left(\mathrm{kg} \mathrm{ha}^{-1}\right)$} \\
\hline P1 & 71.06 & 83.32 & 91.38 & 66.29 & 78.30 & 86.69 \\
\hline P2 & 81.83 & 91.23 & 101.45 & 77.78 & 85.55 & 95.52 \\
\hline P3 & 72.15 & 82.86 & 87.48 & 68.18 & 77.93 & 82.23 \\
\hline $\mathbf{P 4}$ & 63.69 & 70.10 & 79.42 & 60.41 & 66.44 & 74.50 \\
\hline $\operatorname{SEm} \pm$ & & 0.88 & & & 1.01 & \\
\hline \multirow[t]{2}{*}{ CD at $(5 \%)$} & & 2.53 & & & 2.90 & \\
\hline & \multicolumn{6}{|c|}{ Nitrogen uptake by stover $\left(\mathrm{kg} \mathrm{ha}^{-1}\right)$} \\
\hline P1 & 45.67 & 51.45 & 56.49 & 41.54 & 47.10 & 50.87 \\
\hline $\mathbf{P 2}$ & 53.18 & 58.39 & 65.47 & 48.42 & 52.79 & 58.65 \\
\hline $\mathbf{P 3}$ & 43.66 & 49.68 & 55.11 & 39.99 & 44.27 & 49.71 \\
\hline $\mathbf{P 4}$ & 36.93 & 40.44 & 46.14 & 34.36 & 37.41 & 42.05 \\
\hline SEm \pm & & 0.20 & & & 0.33 & \\
\hline \multirow{2}{*}{ CD at $(5 \%)$} & & 0.59 & & & 0.95 & \\
\hline & \multicolumn{6}{|c|}{ Phosphorus uptake by grain $\left(\mathrm{kg} \mathrm{ha}^{-1}\right)$} \\
\hline P1 & 16.30 & 20.72 & 23.34 & 15.78 & 19.55 & 22.13 \\
\hline $\mathbf{P 2}$ & 19.63 & 21.98 & 25.13 & 18.56 & 20.90 & 23.68 \\
\hline $\mathbf{P 3}$ & 16.59 & 19.80 & 21.19 & 16.18 & 19.01 & 19.68 \\
\hline P4 & 15.14 & 17.34 & 20.07 & 14.31 & 16.18 & 18.75 \\
\hline SEm \pm & & 0.22 & & & 0.28 & \\
\hline \multirow[t]{2}{*}{ CD at $(5 \%)$} & & 0.65 & & & 0.82 & \\
\hline & \multicolumn{6}{|c|}{ Phosphorus uptake by stover $\left(\mathrm{kg} \mathrm{ha}^{-1}\right)$} \\
\hline P1 & 8.81 & 11.97 & 14.04 & 10.24 & 12.09 & 13.60 \\
\hline $\mathbf{P 2}$ & 11.50 & 12.80 & 15.31 & 11.87 & 13.10 & 14.81 \\
\hline $\mathbf{P 3}$ & 8.28 & 10.55 & 12.16 & 9.92 & 11.39 & 12.27 \\
\hline $\mathbf{P 4}$ & 7.56 & 9.21 & 11.12 & 8.79 & 9.95 & 11.52 \\
\hline $\operatorname{SEm} \pm$ & & 0.03 & & & 0.21 & \\
\hline \multirow[t]{2}{*}{ CD at $(5 \%)$} & & 0.10 & & & NS & \\
\hline & \multicolumn{6}{|c|}{ Potassium uptake by grain $\left(\mathrm{kg} \mathrm{ha}^{-1}\right)$} \\
\hline P1 & 14.48 & 18.45 & 21.16 & 14.96 & 18.43 & 21.14 \\
\hline $\mathbf{P 2}$ & 17.58 & 19.78 & 22.74 & 17.62 & 19.89 & 22.58 \\
\hline P3 & 14.70 & 17.68 & 18.98 & 15.35 & 18.05 & 18.67 \\
\hline P4 & 13.38 & 15.45 & 17.97 & 13.53 & 15.31 & 17.80 \\
\hline SEm \pm & & 0.23 & & & 0.29 & \\
\hline \multirow[t]{2}{*}{ CD at (5\%) } & & 0.66 & & & 0.83 & \\
\hline & \multicolumn{6}{|c|}{ Potassium uptake by stover $\left(\mathrm{kg} \mathrm{ha}^{-1}\right)$} \\
\hline P1 & 97.80 & 107.05 & 113.10 & 87.80 & 95.97 & 101.39 \\
\hline P2 & 107.15 & 112.90 & 123.27 & 95.88 & 101.75 & 111.01 \\
\hline P3 & 98.34 & 106.63 & 113.16 & 88.09 & 94.83 & 100.51 \\
\hline P4 & 93.18 & 99.32 & 106.33 & 82.28 & 88.13 & 95.12 \\
\hline SEm \pm & \multicolumn{3}{|c|}{0.47} & \multicolumn{3}{|c|}{0.68} \\
\hline CD at $(5 \%)$ & & 1.36 & & & 2.04 & \\
\hline
\end{tabular}


Among different nitrogen levels maximum nitrogen uptake by stover was recorded with $180 \mathrm{~kg} \mathrm{~N} \mathrm{ha}^{-1}$ and lowest with $120 \mathrm{~kg} \mathrm{~N} \mathrm{ha}^{-1}$ during both the crop seasons. Interaction effect of planting methods with nitrogen levels on nitrogen uptake by stover of maize data (Table 5) revealed that it was significantly higher in FSZT planted maize under N3 (64.47 and $58.65 \mathrm{~kg} \mathrm{ha}^{-1}$, in the two crop seasons) but was at par with FSZT under N2 during 2013 and 2014 crop seasons.

The uptake pattern of phosphorus and potassium by grain and stover of maize with various planting methods, Maize hybrids and successive levels of nitrogen was found similar to the uptake pattern of nitrogen by grain and stover of maize. However, intraction effect between various treatments also found similar trend as nitrogen.

Nutrient uptake by grain and straw of maize was found to increase with FSZT, HQPM -5 hybrid maize hybrid and increasing fertility level from $120 \mathrm{~kg} \mathrm{~N}^{-1}$ to $180 \mathrm{~kg} \mathrm{~N}^{-1}$. This was due to increase in dry matter accumulation, grain, straw and biological yield. Among different $\mathrm{N}$ levels maximum nutrient uptake by grain and stover of maize was recorded with $180 \mathrm{~kg} \mathrm{~N} \mathrm{ha}^{-1}$ and lowest with $120 \mathrm{~kg} \mathrm{~N} \mathrm{ha}^{-1}$. The same trend was observed with phosphorus and potassium uptake during both the crop seasons. The increase in NPK uptake by fertilizer application has also been reported by Ahmed (1992); Bangarwa et al., (1992); Varughese and Iruthayaraj, (1996); Selvaraju and Iruthayaraj (1994).

On the basis of experimental findings, it may concluded that planting of maize under FSZT with HQPM-5 and $180 \mathrm{~kg} \mathrm{~N}^{-1}$ was found best with respect to grain and stover yield, nitrogen, phosphorus and potassium uptake by grains and stover over other treatment combination. The increased dose of fertilization by nitrogen increases the growth, yields as well as it increased nutrient uptake.

\section{References}

Ahmed, B. 1992. Derivation of fertilizer maize response and economic optima in fertilizer use. Pakistan Journal of Agricultural Research. 30 (2), 247-252.

Anilkumar and Thakur, K.S. 2004. Effect of integrated nutrient managemet on promising composite maize (Zea mays L.) varieties under rainfed mid-hill conditions of Himachal Pradesh. Indian Journal of Agricultural Sciences. 74 (1), 40-42.

Anonymous 2013. Vision 2030. Directorate of Maize Research, New Delhi.

Anonymous 2015a. Indian Maize Summit 2014 Report, Directorate of Economics and Statistics, Department of Agriculture and Co-operation, FICCI, New Delhi.

Anonymous 2015b. www.agriharyana.nic.in, Department of Agriculture, Haryana.

Bangarwa, A. S., Kairon, M. S. and Singh, K. 1992. Effect of plant density and level and proportion on growth, yield and yield components of winter maize. Indian Journal of Agricultural Sciences. 58(11), 854-856.

Bhatnagar, G.S., Sharma, G.L. and Chaplot, P.G. 1994. Long term effect of continuous maize-wheat cropping system and manuring on soil fertility and stability in crop yield. Indian Journal of Agricultural Science. 64 (12), 821-823.

Brar, B.S., Dhillon, N.S. and China, H.S. 2001. Integrated use of farm yard manure and inorganic fertilizers in maize (Zea mays L.). Indian Journal of Agricultural Sciences. 71 (9), 605-607.

Cochran, W.G. and Cox, G.M. 1959. Experimental Designs, John Willey Pub., New York. 
Dawadi, D.R. and Sah, S.K. 2012. Growth and Yield of Hybrid Maize (Zea mays L.) in Relation to Planting Density and Nitrogen Levels during Winter Season in Nepal, Tropical Agricultural Research. 23 (3), 218 - 227.

DES. 2014. Area, production and productivity of crops. Agricultural Statistics at a Glance. Directorate of Economics and Statistics, DAC, GOI, pp.105.

Halemani, H.L., Hegde, D.M. and Kudasomannavar, B.T. 1980a. Response of maize (Zea mays L.) genotypes to nitrogen application under irrigated conditions. Mysore Journal of Agricultural Sciences. 14, 200-205.

Halemani, H.L., Hegde, D.M. and Kudasomannavar, B.T. 1980b. Response of somepromising maize ( $\mathrm{Zea}$ mays L.) genotypes to nitrogen fertilization under rainfed conditions of transition tract. Mysore Journal of Agricultural Sciences. 14, 206-210.

Jat, M. L., Srivastava, A., Sharma, S.K., Gupta, R. K., Zaidi, P.H., Rai, H. K. and Srivastavasan, G. 2005. Evaluation of maize-wheat cropping system under double no-till practice in Indo-Gangetic Plains of India. In: Proceeding of $9^{\text {th }}$ Asian Regional Maize Workshop. 5-9 September, Beijing, China, PP. 25-26.
Jat, M.L., Pal, S.S., Ravinder Singh, Singh, D. and Gill, M.S. 2008. Effect of moisture regimes and nitrogen management options on crop and water productivity and nitrogen-use efficiency in maize (Zea mays)-wheat (Triticum aestivum) cropping system. Indian Journal of Agricultural Sciences. 78 (10), 881-883.

Jat, M.L., Zaidi, P.H., Rai, H.K. and Gupta, R.K. 2007. Screening of Quality Protein Maize hybrids with different Resource Conserving Technologies. Indian Journal of Agronomy. 39 (1and2), 142145.

Panse, V.G. and Sukhatme, P.R. 1978. Statistical Methods for Agricultural Workers. ICAR, New Delhi.

Selvaraju, R. and Iruthayaraj, M. R. 1994. Influence of irrigation and nitrogen levels on growth and yield of maize. Madras Agricultural Journal. 81(8), 418-420.

Sewhag, M., Phogat, V.K., Dhindwal, A. S. and Hooda, I.S. 2008. Influence of planting methods and moisture regimes on yield and yield attributes of cluster bean (Cyamopsis tetragonoloba). Annals of Agri-Bio Research. 13(2), 127-131.

\section{How to cite this article:}

Dheeraj Kr. Tiwari, V.S. Hooda, S.K. Thakral, Ashok Yadav and Sharma, M.K. 2018. Effect of Planting Methods, Maize Hybrids and Nitrogen Levels on Nutrient Uptake of High Quality Protein Maize (Zea mays L.). Int.J.Curr.Microbiol.App.Sci. 7(05): 246-253. doi: https://doi.org/10.20546/ijcmas.2018.705.032 